\title{
A comparative study to assess the efficacy of dinoprostone and misoprostol in labour induction
}

\author{
Neelima V. Nair*, Divya R. Prasad, Geethanjali S. Mohan
}

\begin{abstract}
Department of Obstetrics and Gynaecology, Sree Gokulam Medical College and Research Foundation, Vejaramoodu,
\end{abstract} Kerala, India

Received: 23 February 2016

Accepted: 18 March 2016

\section{*Correspondence:}

Dr. Neelima V. Nair,

E-mail: drneelimavnair@gmail.com

Copyright: () the author(s), publisher and licensee Medip Academy. This is an open-access article distributed under the terms of the Creative Commons Attribution Non-Commercial License, which permits unrestricted non-commercial use, distribution, and reproduction in any medium, provided the original work is properly cited.

\begin{abstract}
Background: Induction of labour is the non-spontaneous initiation of uterine contractions, prior to their spontaneous onset leading to progressive effacement and dilation of cervix and delivery of the baby. The objective of this study to compare efficacy of induction of labour with dinoprostone and misoprostol with respect to induction delivery interval, oxytocin augmentation, type of delivery and cost effectiveness.

Methods: 200 Patients admitted to labour ward of Sree Gokulam Medical College and Research Foundation, Vejaramoodu, Kerala, India with an indication of induction of labour and unfavorable cervices were randomly assigned to receive either intravaginal misoprostol or intracervical dinoprostone between December 2012 and May 2014.

Results: Average induction to delivery interval among misoprostol group was $21.6+4.2$ hours and that of dinoprostone was 29.1+4.2 hours. Dinoprostone group had significant longer duration than misoprostol group in induction delivery interval.64\% of misoprostol group had spontaneous onset of labour whereas only $31 \%$ of dinoprostone group had spontaneous labour onset. Mean bishop's score change over 6 and 12 hours was significantly greater in the misoprostol group. There was no significant difference in the mode of delivery or rate of caesarean section in both the groups.

Conclusions: Misoprostol is an effective and economical drug for induction of labour, which is easy to preserve and administer. It shortness the induction delivery interval with less need for oxytocin compared to dinoprostone.
\end{abstract}

Keywords: Misoprostol, Dinoprostone, Induction of labour, Oxytocin

\section{INTRODUCTION}

Induction of labour is the non-spontaneous initiation of uterine contractions, prior to their spontaneous onset leading to progressive effacement and dilation of cervix and delivery of the baby. ${ }^{1}$ The overall rates of induction of labour has increased significantly over the last decade due to the availability of varied options. Even today no method of induction is absolutely certain and the pursuit for such a method still continues.

PGE2 has been used for more than a decade for cervical ripening and labour induction and is approved by food and drug administration. The method of administration that has been explored thoroughly is endocervical dinoprostone or prostaglandin E2. Though this is widely used, it is expensive and required refrigeration for storage.

It was only a matter of time before a comparably cheap, safe and effective vaginally administered Prostaglandin with limited side effects would be available. Misoprostol or PGE1 tablet fitted those criteria admirably.

In this study, cervical ripening with endocervical prostaglandin E2 gel, and the new one intravaginal prostaglandin E1 tablet are compared with regard to efficacy. 


\section{METHODS}

Total of 200 patients (100 in each group) admitted to the labour room of Sree Gokulam Medical College and Research Foundation, Vejaramoodu, India with an indication of induction of labour. Out of total sample, 100 patients each were induced with misoprostol and dinoprostone. The study was conducted from December 2012 to May 2014. Primi gravid women with singleton fetus in cephalic presentation at gestational age above 37 weeks with reactive fetal heart pattern, bishop's score $<6$ and no contraindication to vaginal delivery were included in the study.

Women with previous caesarean section or any uterine surgery, malpresentation, multiparity, abnormal fetal heart rate pattern, placenta previa and known allergy to prostaglandins were excluded from the study.

200 patients with an indication for induction of labour were selected for the study. The informed consent was taken from those patients admitted in labour room in proforma approved by institutional ethical committee. The patients were randomly divided into 2 groups. 100 patients with an indication for induction received $25 \mu \mathrm{g}$ misoprostol intravaginally and same dose repeated after 6 hours if no progress seen.

Alternately 100 patients with an indication for labour received $0.5 \mathrm{mg}$ intracervical dinoprostone gel and same dose repeated after $6 \mathrm{hrs}$ if no progress seen. Patients were evaluated by modified bishop's score and admission test for fetal wellbeing. Patients with score less than 6 and positive admission test were induced. After drug insertion, patients were monitored for signs of labour, maternal vitals, fetal heart rate and progress of labour. A partogram was maintained in all patients induced. Oxytocin was started depending on the modified bishops's score and in the absence of adequate uterine contraction or in case of arrest of dilatation. Membranes were ruptured when cervix was completely effaced with a dilatation of more than $3 \mathrm{~cm}$ or at the onset of active stage of labour. At the end of the study period, the efficacy of misoprostol and dinoprostone were compared with respect to the study variables. Labour and delivery parameters including, interval from start of induction to delivery, mean number of doses until delivery, number of patients requiring oxytocin augmentation, mode of delivery were compared.

\section{Statistical Analysis}

Data was entered into a computer using MS Excel software and was analyzed using appropriate statistical test like chi square test and test.

\section{RESULTS}

This average gestational age of misoprostol group was $38.6 \pm 1.7$ weeks and that of dinoprostone group was $38.8 \pm 1.1$ weeks. Both groups were comparable according to gestational age $(p>0.05)$. $67 \%$ of misoprostol group and $77.0 \%$ of dinoprostone group had 2 doses. There was no significant difference in number of doses between the two groups $(\mathrm{p}>0.05)$. 67.0\% of misoprostol group and $59.0 \%$ of dinoprostone group had MBS before induction was 3.

Table 1: Association between method of induction and MBS 6 hours after induction.

\begin{tabular}{|c|c|c|c|c|c|c|}
\hline \multirow{2}{*}{ MBS 6 hours after induction } & \multicolumn{2}{|c|}{ Misoprostol } & \multicolumn{2}{|c|}{ Dinoprostone } & \multirow[b]{2}{*}{$\chi^{2}$} & \multirow[b]{2}{*}{$\mathbf{p}$} \\
\hline & Count & Percent & Count & Percent & & \\
\hline $1-3$ & 0 & 0.0 & 20 & 20.0 & \multirow{3}{*}{$36.2^{* *}$} & \multirow{3}{*}{$<0.001$} \\
\hline $4-6$ & 68 & 68.0 & 73 & 73.0 & & \\
\hline $7-10$ & 32 & 32.0 & 7 & 7.0 & & \\
\hline
\end{tabular}

**Significant at 0.01 level.

There was no significance difference in MBS before induction $(p>0.05)$. 32.0\% of misoprostol group had MBS 6 hours after Induction 7-10 whereas only 7.0\% of dinoprostone group had MBS 6 hours after Induction 710. The observed difference was statistically significant $(\mathrm{p}<0.05)$ (Table 1).

$64.0 \%$ of Misoprostol group had spontaneous labour onset whereas only $31.0 \%$ of the dinoprostone group had Spontaneous labour onset. Misoprostol group had significantly high rate of spontaneous labour onset than dinoprostone $(\mathrm{p}<0.05)$ (Table 2$)$.
$81.0 \%$ of misoprostol group and $71.0 \%$ of dinoprostone group had vaginal delivery. The observed difference is not statistically significant ( $>00.05$ ) (Table 3 ).

Average duration of delivery interval among misoprostol group was $21.6 \pm 4.3$ and that of the dinoprostone group was 29.1 \pm 4.2 . Dinoprostone group had significantly longer duration than misoprostol group in the case of delivery interval $(\mathrm{p}<0.05)$ (Table 4$)$. 
Table 2: Association between method of induction and labour onset.

\begin{tabular}{|c|c|c|c|c|c|c|}
\hline \multirow{2}{*}{ Labour Onset } & \multicolumn{2}{|c|}{ Misoprostol } & \multicolumn{2}{|c|}{ Dinoprostone } & \multirow{2}{*}{$x^{2}$} & \multirow[b]{2}{*}{$\mathbf{p}$} \\
\hline & Count & Percent & Count & Percent & & \\
\hline Spontaneous & 64 & 64 & 31 & 31 & \multirow{2}{*}{$21.84 * *$} & \multirow{2}{*}{$<0.001$} \\
\hline Oxytocin augmentation & 36 & 36 & 69 & 69 & & \\
\hline
\end{tabular}

Table 3: Association between method of induction and mode of delivery.

\begin{tabular}{|c|c|c|c|c|c|c|}
\hline \multirow{2}{*}{ Mode of delivery } & \multicolumn{2}{|c|}{ Misoprostol } & \multicolumn{2}{|c|}{ Dinoprostone } & \multirow{2}{*}{$\chi^{2}$} & \multirow[b]{2}{*}{ p } \\
\hline & Count & Percent & Count & Percent & & \\
\hline Vaginal Delivery & 81 & 81 & 71 & 71 & \multirow{3}{*}{3.144} & \multirow{3}{*}{0.208} \\
\hline Emergency LSCS & 10 & 10 & 18 & 18 & & \\
\hline Instrumental Delivery & 9 & 9 & 11 & 11 & & \\
\hline
\end{tabular}

Table 4: Comparison of induction delivery interval based on method of induction.

\begin{tabular}{|llllll|}
$\begin{array}{l}\text { Method of } \\
\begin{array}{l}\text { Induction } \\
\text { Misoprostol }\end{array}\end{array}$ & 21.6 & 4.3 & 100 & $12.47 * *$ & 0.000 \\
\hline Dinoprostone & 29.1 & 4.2 & 100 & & \\
\hline
\end{tabular}

\section{DISCUSSION}

In this study synthetic PGE1, analogue intravaginal misoprostol has been compared with the time tested PGE2 gel intracervical dinoprostone gel with respect to outcome of induction in terms of change in bishops score, induction delivery interval, mode of delivery and need for oxytocin augmentation. In the present study only primigravidas were selected in both groups.85.0\% of misoprostol and $74.0 \%$ of dinoprostone were $18-25$ years of age. Both groups were comparable according to age. Average gestational age of misoprostol group was $38.6 \pm 1.7$ weeks and that of dinoprostone group was $38.8 \pm 1.1$ weeks. Both groups were comparable according to gestational age $(\mathrm{P}>0.05)$. In this study the dose of misoprostol was reduced to 25 micrograms and the duration of application was increased to 6 hours. The dose of dinoprostone was reduced from $1 \mathrm{mg}$ to $0.5 \mathrm{mg}$ and for a maximum of two doses rather than three. $67 \%$ of misoprostol group and $77.0 \%$ of dinoprostone group had 2 doses. There was no significance difference in No of dose between the two groups $(p>0.05)$. The dosage regimen in study by Meyer $\mathrm{M}$ was misoprostol $0.25 \mathrm{ug}$ intravaginally or dinoprostone gel $0.5 \mathrm{mg}$ intracervically. ${ }^{2}$ The dosage regimen in study by Calder of misoprostol 25 micrograms (50 micrograms in nulliparous women with bishop score $<$ or $=4$ ) followed by 25 micrograms after 4 and 8 hours, or dinoprostone $3 \mathrm{mg}$ followed by 3 mg after 6 hours. The dosage regimens in study by Chitrakar NS were $25 \mu \mathrm{g}$ misoprostol versus $0.5 \mathrm{mg}$ dinoprostone. The doses were repeated after 6 hours if the bishop score was less than $6 .{ }^{3,4}$
$67.0 \%$ of Misoprostol group and $59.0 \%$ of Dinoprostone group had MBS before induction was 3. There was no significance difference in MBS before induction (p>0.05).32.0\% of misoprostol group had MBS $6 \mathrm{hrs}$ after induction 7-10 whereas only $7.0 \%$ of dinoprostone group had MBS 6 hours after Induction 7-10. The observed difference was statistically significant $(\mathrm{p}<0.05)$ Urale $\mathrm{S}$ et al observed mean bishop's score at 6 hours was $5.9 \pm 2.9$ in primigravida. In study by Mar Oliveira TA, Melo EM, Aquino MM and Neto $M$ the ripening of cervix was higher in the group treated with misoprostol $(87.3 \%)$ versus $75.6 \%(\mathrm{p}=0.04)$.

$64.0 \%$ of misoprostol group had spontaneous labour onset whereas only $31.0 \%$ of the dinoprostone group had spontaneous labour onset. Misoprostol group had significantly high rate of spontaneous labour onset than dinoprostone $(\mathrm{p}<0.05)$ (oxytocin augmentation was more in dinoprostone group-69\% than in misoprostol group$36 \%$ ). In a study by In Neiger R. Greaves PC $50 \%$ in the misoprostol group required oxytocin, whereas $90 \%$ in the dinoprostone group required oxytocin augmentation $(\mathrm{P}=0.008)$. The studies by Ramsey and Meyer et al had more spontaneous onset of labour in the misoprostol group, which was also significant $(\mathrm{p}<0.05$ and $\mathrm{p}=$ 0.002). ${ }^{8}$ In study by Mar Oliveira TA, Melo EM, Aquino $\mathrm{MM}$ and Neto $\mathrm{M}$ the use of oxytocin was necessary in $58.8 \%$ of them isoprostol group and $57.3 \%$ in the dinoprostone group. ${ }^{5}$

$81.0 \%$ of misoprostol group and $71.0 \%$ of dinoprostone group had vaginal delivery. The observed difference is not statistically significant. In misoprostol group the caesarean section rate was $10 \%$ and in dinoprostone group was $18 \%$ which is not statistically significant. .In misoprostol group the instrumental delivery rate was $9 \%$ and in dinoprostone group was $11 \%$ which is not statistically significant. Failed induction was the primary indication of caesarean section delivery in both groups, with no significant difference between them. Chang $\mathrm{CH}$ et al, Neiger R Greaves PC demonstrated that both modalities had similar incidences of cesarean delivery. ${ }^{6,7}$ 
Average induction to delivery interval among misoprostol group was $21.6 \pm 4.3$ hours and that of the dinoprostone group was $29.1 \pm 4.2$ hours. Dinoprostone group had significantly longer duration than misoprostol group in the case of induction delivery interval $(p<0.05)$. In study by Ramsey et al the induction delivery interval was 23.9 hours in misoprostol group and 31.1hours in dinoprostone group. Van $G$ et al in their study concluded that the median induction-to-vaginal delivery interval was approximately 6 hours longer in the misoprostol group (25 versus 19 hours, $\mathrm{p}=0.008) .{ }^{9}$ Where as in an Indian study by Nanda et al demonstrated that the mean induction to delivery interval is five hours shorter in misoprostol group $(13.30+78.74$ versus $18.53+11.33$ $\mathrm{p}=0.011) .^{10}$

\section{CONCLUSIONS}

The uses of prostaglandins provide an effective method for achieving the induction of labour. Misoprostol and dinoprostone are $\mathrm{s}$ effective for cervical ripening and labour induction. On the basis of our study, misoprostol appears to be an effective agent for induction and augmentation of labour when compared to dinoprostone. The results of labour outcome convincingly prove that in the patients treated with misoprostol, induction interval was shorter, the ripening of cervix was higher, requirement of oxytocin augmentation is less and incidence of caesarean section were reduced. Misoprostol is cost-effective when compared to dinoprostone. Misoprostol is stable at room temperature and does not need refrigeration whereas dinoprostone requires refrigeration. As such it may be preferred as the agent of choice in the induction of labour especially in a developing country like ours, allowing considerable cost saving.

\section{ACKNOWLEDGEMENTS}

Authors would like thanks to Department of Obstetrics and Gynaecology, Sree Gokulam Medical College and Research Foundation, Vejaramoodu, Kerala, India.

Funding: No funding sources Conflict of interest: None declared

Ethical approval: The study was approved by the Institutional Ethics Committee

\section{REFERENCES}

1. Arulkumaran. The management of labour. $3^{\text {rd }}$ ed. 2011.

2. Meyer M, Pflum J, Howard D. Outpatient misoprostol compared with dinoprostone gel for preinduction cervical ripening: a randomized controlled trial. Obstet Gynecol. 2005;105(3):46672.

3. Calder AA, Loughney AD, Weir CJ, Barber JW. Induction of labour in nulliparous and multiparous women: a UK, multicentre, open-label study of intravaginal misoprostol in comparison with dinoprostone. BJOG Int J Obstet Gynaecol. 2008;115(10):1279-88.

4. Chitrakar NS. Comparison of Misoprostol versus Dinoprostone for pre-induction cervical ripening atterm. J Nepal Health Res Counc. 2012;10(1):10-5.

5. Oliveira TA, Melo EMV, Aquino MMA, Neto CM. Efficacy of dinoprostone and misoprostol for labor induction in nulliparous women. Rev Bras Ginecol E Obstetrícia Rev Fed Bras Soc Ginecol E Obstetrícia. 2011;33(3):118-22.

6. Chang $\mathrm{CH}$, Chang FM. Randomized comparison of misoprostol and dinoprostone for pre-induction cervical ripening and labor induction. J Formos Med Assoc Taiwan Yi Zhi. 1997;96(5):366-9.

7. Neiger R, Greaves PC. Comparison between vaginal misoprostol and cervical dinoprostone for cervical ripening and labor induction. Tenn Med J Tenn Med Assoc. 2001;94(1):25-7.

8. Ramsey PS, Meyer L, Walkes BA, Harris D, Ogburn PL, Heise RH, et al. Cardiotocographic abnormalities associated with dinoprostone and misoprostol cervical ripening. Obstet Gynecol. 2005;105(1):85-90.

9. Gemund NV, Scherjon S, LeCessie S, Leeuwen JHS, Roosmalen J, Kanhai HHH. A randomised trial comparing low dose vaginal misoprostol and dinoprostone for labour induction. BJOG Int J Obstet Gynaecol. 2004;111(1):42-9.

10. Nanda S, Singhal SR, Papneja A. Induction of labour with intravaginal misoprostol and prostaglandin E2 gel: a comparative study. Trop Doct. 2007;37(1):21-4.

Cite this article as: Nair NV, Prasad DR, Mohan GS. A comparative study to assess the efficacy of dinoprostone and misoprostol in labour induction. Int J Reprod Contracept Obstet Gynecol 2016;5:1457-60. 